Jerzy Bieluk

Uniwersytet w Bialymstoku

\title{
ZNIESIENIE WSPÓŁWŁASNOŚCI GOSPODARSTWA ROLNEGO W KONTEKŚCIE ZASADY SŁUSZNOŚCI
}

\section{Zagadnienia wstępne}

Przedmiotem niniejszej publikacji jest analiza regulacji zawartej w art. 213 k.c. i 214 k.c. dotyczącej znoszenia współwłasności gospodarstwa rolnego, w szczególności zawartych w powyższych przepisach ogólnych sformułowań odnoszących się do zasad przyznania gospodarstwa rolnego jednemu ze współwłaścicieli, w kontekście zasady słuszności. Powyższe przepisy zawierają szereg sformułowań niedookreślonych, których konkretyzacja dokonuje się w procesie orzeczniczym. Spośród nich w szczególności analizy wymagają klauzula interesu społeczno-gospodarczego oraz należytej gwarancji właściwego prowadzenia gospodarstwa rolnego.

Ogólną zasadą obowiązującą zgodnie z art. 211 k.c. przy zniesieniu współwłasności jest prymat podziału fizycznego. Preferowanie przez ustawodawcę takiego sposobu zniesienia współwłasności rzeczy widoczne jest także w przepisach regulujących postępowanie cywilne, a zwłaszcza z art. 623 k.p.c., który dopuszcza podział fizyczny rzeczy nawet wówczas, gdy brak jest porozumienia stron w przedmiocie sposobu zniesienia współwłasności, a zachodzą warunki do dokonania podziału w naturze. W takim przypadku sąd dokonuje podziału na części odpowiadające wartością udziałom współwłaścicieli z uwzględnieniem wszelkich okoliczności zgodnie z interesem społeczno-gospodarczym, zaś różnice wartości wyrównuje się przez dopłaty pieniężne. Jednak podział fizyczny nie jest możliwy, jeżeli byłby sprzeczny z przepisami ustawy lub ze społeczno-gospodarczym przeznaczeniem rzeczy, albo jeżeli pociągałby za sobą istotną zmianę rzeczy lub znaczne zmniejszenie jej wartości. W każdej z tych sytuacji rzecz, która nie daje się podzielić, może być przyznana stosownie do okoliczności jednemu ze współwłaścicieli z obowiązkiem spłaty pozostałych lub sprzedana stosownie do przepisów k.p.c. (art. $212 \S 2$ k.c.).

Określone powyżej reguły ulegają modyfikacji oraz uzupełnieniu, w przypadku gdy mamy do czynienia ze zniesieniem współwłasności gospodarstwa rolnego. Ko- 
deks cywilny reguluje zasady znoszenia współwłasności gospodarstwa rolnego ${ }^{1}$ w sposób dokładniejszy, bardziej szczegółowy niż w przypadku innych przedmiotów współwłasności.

Ustawodawca nie ingeruje w zgodne podziały gospodarstwa rolnego między współwłaścicielami. ${ }^{2}$ Jednak w przypadku braku zgody (lub w przypadku, gdy pomimo zgody między współwłaścicielami postępowanie toczy się przed sądem), reguła ogólna zawarta w art. 211 k.c. ulega uzupełnieniu o art. 213 k.c. Tym samym, jeżeli zniesienie współwłasności gospodarstwa rolnego przez podział między współwłaścicieli byłoby sprzeczne z zasadami prawidłowej gospodarki rolnej, sąd przyzna gospodarstwo temu współwłaścicielowi, na którego wyrażą zgodę wszyscy współwłaściciele. Wówczas wchodzi w grę procedura wyboru osoby, której gospodarstwo ma być przyznane, uregulowana w art. 214 i 215 k.c.

Zgodnie z artykułami 213-217 k.c. podział gospodarstwa rolnego ograniczony jest bardziej niż podział innych przedmiotów współwłasności. ${ }^{3}$ Przepisy kodeksu cywilnego określają szczegółowo, w jaki sposób taki podział miałby się dokonać, dając sądowi pewne wytyczne, jak postępować w określonej sytuacji.

Zaznaczyć należy, iż regulacja powyższa ma duże znaczenie praktyczne z uwagi na brzmienie przepisu art. 1070 k.c., który przewiduje odpowiednie stosowanie przepisów o podziale gospodarstw rolnych przy zniesieniu współwłasności - a zatem art. 213 i następnych - do podziału gospodarstwa rolnego, które należy do spadku. O ile bowiem powstanie współwłasności na przykład w wyniku wspólnego zakupu gospodarstwa rolnego nie zdarza się często, o tyle większość gospodarstw rolnych w Polsce wchodzi w wyniku spadkobrania do majątku spadkowego, będącego przedmiotem wspólności masy spadkowej.

1 Pojęcie zniesienia współwłasności gospodarstwa rolnego może budzić uzasadnione wątpliwości przede wszystkim ze względu na to, iż sam status prawny pojęcia gospodarstwa rolnego nie jest w pełni jasny i wywołuje kontrowersje u przedstawicieli doktryny. Jeżeli przyjąć, że istotą gospodarstwa rolnego zgodnie z kodeksem cywilnym jest czynnik organizacji - może wtedy istnieć gospodarstwo rolne oparte o stosunki zobowiązaniowe (dzierżawiona ziemia, leasingowane maszyny). Wówczas pojęcie zniesienia współwłasności gospodarstwa rolnego ma raczej charakter podziału pewnej zorganizowanej całości gospodarczej, w której stosunki własnościowe są kwestią wtórną. Dla potrzeb niniejszego artykułu przyjęto, iż gospodarstwo rolne to pewna całość gospodarcza, której podstawowym składnikiem jest grunt rolny, będący własnością rolnika. W praktyce spory i wątpliwości rodzą się przy sprawach, które dotyczą podziału nieruchomości, wchodzących w skład gospodarstwa rolnego i będących przedmiotem stosunków własnościowych.

2 Zob. m.in. A. Cisek, (w:) E. Gniewek (red.), Kodeks cywilny. Komentarz, Warszawa 2011, s. 364. Nawet jednak w przypadku umownego zniesienia współwłasności gospodarstwa rolnego zastosowania będą miały ograniczenia wynikające z przepisów dotyczących podziału nieruchomości zawarte w ustawie z dnia 21 sierpnia 1997 r. o gospodarowaniu nieruchomościami (tekst jednolity Dz.U. 2014 r. poz. 518 z późn. zm.).

3 Zob. postanowienie Sądu Najwyższego z dnia 24 stycznia 2013 r., V CSK 132/12, LEX nr 1296719, gdzie wskazano, że „w razie przyznania rzeczy bądź prawa podlegającemu postępowaniu podziałowemu jednemu ze współwłaścicieli, przepisy prawa materialnego zawierają uregulowania zawierające pewne wytyczne dla sądu, którymi powinien kierować się przy wyborze osoby, któremu dana rzecz bądź prawo jest przydzielane. Takie szczególne przepisy zawarte są w art. 213 oraz art. $214 \S 1$ i 2 k.c. dotyczących gospodarstwa rolnego. W stosunku do innych rzeczy (bądź praw), jak stanowi art. 212 § 2 k.c. w zw. z art. 1035 k.c. i art. 46 k.r.o. (w odniesieniu do byłego majątku wspólnego małżonków), może być ono przyznane jednemu ze współwłaścicieli „stosownie do okoliczności”. W istocie więc decyzja w tym przedmiocie należy do sądu, który przyznając rzecz (prawo) jednemu ze współwłaścicieli, powinien uwzględnić wszelkie okoliczności sprawy". 
Analiza pojęcia gospodarstwa rolnego zdecydowanie wykracza poza ramy niniejszego artykułu. Podkreślić jednak trzeba, iż z pewnością należy stosować tu definicję z art. $55^{3}$ k.c., zgodnie z którą za gospodarstwo rolne uważa się grunty rolne wraz z gruntami leśnymi, budynkami lub ich częściami, urządzeniami i inwentarzem, jeżeli stanowią lub mogą stanowić zorganizowaną całość gospodarczą oraz prawami związanymi z prowadzeniem gospodarstwa rolnego. ${ }^{4}$ Dla potrzeb niniejszego artykułu zasada słuszności w prawie prywatnym będzie rozumiana jako mechanizm korekcyjny wobec prawa stanowionego, którego istota polega na odwołaniu się do pojęć słuszności i sprawiedliwości. ${ }^{5}$

\section{Art. 213 k.c. - istota ograniczenia znoszenia współwłasności}

Zniesienie współwłasności gospodarstwa rolnego ma kilka kontekstów. Przede wszystkim jest to kontekst gospodarczy - ochrona gospodarstwa rolnego jako jednostki produkcyjnej wytwarzającej produkty żywnościowe, ale również kontekst socjalny - ochrona gospodarstwa rolnego jako warsztatu pracy rolnika, jako miejsca jego zatrudnienia, źródła dochodu i utrzymania dla rodziny rolnika. Oba te uwarunkowania znajdują odbicie w pojęciu gospodarstwa rodzinnego, które zgodnie z Konstytucją podlega ochronie. Przejawem szczególnej polityki wobec gospodarstw rodzinnych jest przepis art. 23 Konstytucji, ${ }^{6}$ zgodnie z którym podstawą ustroju rolnego państwa jest gospodarstwo rodzinne. Pomijając kontrowersje związane z pojęciem gospodarstwa rodzinnego, wynikające przede wszystkim z braku konkretyzacji regulacji konstytucyjnej w ustawach szczegółowych, ${ }^{7}$ podkreślić należy, iż mieszczą się w nim z pewnością owe dwa wskazania - dbałość o jednostkę produkcyjną jako część gospodarki narodowej oraz dbałość o gospodarstwo rolne jako podstawę życia na wsi. Art. 23 Konstytucji stanowi wyraz chęci stosowania preferencyjnej polityki wobec gospodarstw rodzinnych, szczególnie w opozycji do wielkich producentów rolnych, opierających swą działalność na sile najemnej. Jest to też gwarancja ewolucyjnego rozwoju rolnictwa. Jak stwierdził Trybunał Konstytucyjny w wyroku z dnia 31 stycznia 2001 r., ${ }^{8}$ gospodarstwo rodzinne ,powinno stanowić efektywną formę

Szerzej o pojęciu gospodarstwa rolnego zob. m.in. R. Budzinowski, Koncepcja gospodarstwa rolnego w prawie rolnym, Poznań 1992; J. Nadler, Pojęcie indywidualnego gospodarstwa rolnego w prawie rolnym, Wrocław 1976; P. Czechowski, A. Niewiadomski, Gospodarstwo rolne jako masa majątkowa, „Studia luridica Agraria” 2009, t. VIII, s. 47-60; zob. też K. Stefańska, Model indywidualnego gospodarstwa rolnego w świetle znowelizowanego kodeksu cywilnego, PiP 1992, nr 3.

5 Zob. M. Safjan, (w:) M. Safjan (red.), System Prawa Prywatnego. Prawo cywilne - część ogólna. Tom 1, Warszawa 2012, s. 353.

6 Szerzej por. J. Bieluk, Działy specjalne produkcji rolnej. Problemy prawne, Białystok 2014, s. 41.

7 Szerzej o pojęciu gospodarstwa rodzinnego zob. m.in. A. Lichorowicz, Status prawny gospodarstw rodzinnych w ustawodawstwie krajów Europy Zachodniej, Białystok 2000; zob. też. A. Oleszko, Uznanie rodzinnego gospodarstwa rolnego jako konstytucyjnej podstawy polskiego ustroju rolnego (uwagi do Konstytucji z dnia 2 kwietnia 1997 r.), „Rejent” 1997, nr 5, s. 81; zob. też K. Stefańska, Gospodarstwo rodzinne jako element ustroju rolnego, „Studia luridica Agraria” 2002, t. II, s. 171. Wyrok Trybunału Konstytucyjnego z 31 stycznia 2001 r. (sygn. P 4/99). 
gospodarowania pozwalającą prowadzić produkcję rolną w celu nie tylko zapewnienia godziwego utrzymania rodzinom rolniczym, ale także najpełniejszego zaspokojenia potrzeb społeczeństwa. Tylko bowiem tak prowadzone gospodarstwo może stanowić podstawę ustroju rolnego państwa."

$\mathrm{Z}$ powyższych względów art. 213 k.c. wprowadza dodatkowe, w stosunku do regulacji ogólnej (art. 211 k.c.), ograniczenie podziału gospodarstwa rolnego. Przepis ten dopuszcza zniesienie współwłasności gospodarstwa rolnego przez podział między współwłaścicieli jedynie w sytuacji, gdy podział jest zgodny z zasadami prawidłowej gospodarki rolnej. Tym samym zasada zniesienia współwłasności gospodarstwa rolnego poprzez podział w naturze nie ma charakteru bezwzględnego. Zarówno sama możliwość podziału rzeczy wspólnej w naturze, jak i sposób jej podziału uzależniony jest od zgodności ze społeczno-gospodarczym przeznaczeniem rzeczy bądź zgodności z interesem społeczno-gospodarczym. ${ }^{9} \mathrm{~W}$ przypadku gospodarstwa rolnego dochodzi do tego dodatkowy warunek zgodności z zasadami prawidłowej gospodarki rolnej. $Z$ tego też względu sąd w postępowaniu w przedmiocie zniesienia współwłasności gospodarstwa rolnego powinien przy rozstrzygnięciu brać pod uwagę całokształt okoliczności i w sytuacji, gdy po przeprowadzeniu postępowania sądowego uzna, że inny sposób podziału rzeczy niż jej podział w naturze jest bardziej racjonalny może odstąpić od zasady zniesienia współwłasności przez podział fizyczny. ${ }^{10}$

$\mathrm{Z}$ uwagi na konieczność badania przez sąd racjonalności podziału gospodarstwa rolnego $\mathrm{w}$ naturze zgodnie $\mathrm{z}$ art. $619 \S 2$ k.p.c. przy takim podziale gospodarstwa obligatoryjne jest zasięgnięcie opinii biegłych, których rolą jest nie tylko wypowiedzenie się w przedmiocie formy podziału gospodarstwa rolnego, ale i również w przedmiocie samej dopuszczalności podziału gospodarstwa rolnego. Bowiem ocena tego, czy podział gospodarstwa rolnego będzie zgodny z zasadami prawidłowej gospodarki wymaga posiadania wiedzy specjalistycznej. ${ }^{11}$

W sytuacji, gdy zniesienie współwłasności gospodarstwa rolnego przez podział nie jest możliwe z uwagi na przesłanki zawarte w art. 211 k.c. lub ze względu na art. 213 k.c. (sprzeczność z zasadami prawidłowej gospodarki rolnej) i jeżeli sprawa jest rozpatrywana przed sąd, ustawodawca określa przesłanki dalszego postępowania. ${ }^{12}$

9 Zob. postanowienie Sądu Najwyższego z dnia 22 października 2010 r., III CSK 331/09, LEX nr 688860.

10 Zob. postanowienie Sądu Najwyższego z dnia 3 czerwca 2011 r., III CSK 330/10, LEX nr 885041.

11 Zob. postanowienie Sądu Najwyższego z 30 listopada 2007 r., IV CSK 305/07, LEX nr 750015. Szerzej o zasadach prawidłowej gospodarki rolnej jako kryterium ograniczenia podziału zob. M. Durzyńska, Podział nieruchomości, Warszawa 2011, s. 334-335.

12 Zob. tryb postępowania opisany w tezie postanowienia Sądu Najwyższego z dnia 30 października 1978 r. III CRN 214/78 (LEX nr 8143) „Kodeks cywilny preferuje zniesienie współwłasności przez podział fizyczny rzeczy wspólnej. Wynika to wyraźnie z postanowień art. 211, 212 § 2 i 214 k.c. Jeżeli zniesienie współwłasności następuje z mocy orzeczenia sądu, sąd powinien więc przede wszystkim brać pod uwagę ten sposób wyjścia ze wspólności, chyba że współwłaściciele żądają przyznania rzeczy wspólnej jednemu z nich w zamian za spłaty, albo sprzedania stosownie do przepisów kodeksu postępowania cywilnego. W braku takich żądań sąd powinien ustalić, czy istnieje fizyczna i prawna możliwość podziału, a dopiero, gdy podział nie jest dopuszczalny - a przedmiotem podziału jest nieruchomość rolna - znieść współwłasność w sposób określony w art. 214 k.c." 
Wówczas w grę wchodzą kryteria określone w art. 214 k.c. ${ }^{13}$ A mianowicie w razie zgody wszystkich współwłaścicieli sąd przyzna gospodarstwo rolne temu z nich, kto je prowadzi lub stale w nim pracuje, chyba że interes społeczno-gospodarczy przemawia za wyborem innego współwłaściciela. Jednak w sytuacji, gdy warunki powyższe spełnia kilku współwłaścicieli albo jeżeli nie spełnia ich żaden ze współwłaścicieli, sąd przyzna gospodarstwo rolne temu z nich, który daje najlepszą gwarancję jego należytego prowadzenia.

$Z$ reguły sprawy o zniesienie współwłasności gospodarstwa rolnego trafiają do sądu, gdy strony toczą spór co do masy majątkowej, mającej być przedmiotem podziału. Wówczas fakt, że omawiane regulacje posługują się kilkoma sformułowaniami otwartymi, pozwala na znaczną swobodę w procesie decyzyjnym sądu. Tym trudniejsza jest więc rola sądu w uzasadnieniu postanowienia, odwołując się do tak niedookreślonych pojęć.

\section{Interes społeczno-gospodarczy - art. 214 k.c.}

Zgodnie z art. 214 § 1 k.c. w razie braku zgody wszystkich współwłaścicieli, sąd przyzna gospodarstwo rolne temu z nich, który je prowadzi lub stale w nim pracuje, chyba że interes społeczno-gospodarczy przemawia za wyborem innego współwłaściciela. Pierwszeństwo ma zgodnie z powyższą regulacją osoba, która prowadzi gospodarstwo rolne. Przez prowadzenie gospodarstwa rolnego należy rozumieć podejmowanie podstawowych decyzji związanych z funkcjonowaniem gospodarstwa rolnego. ${ }^{14}$ Zgodnie z powyższą regulacją gospodarstwo rolne może zostać przyznane także osobie stale w nim pracującej - czyli osobie takiej jak domownik w rozumieniu przepisów ustawy z dnia 20 grudnia 1990 r. o ubezpieczeniu społecznym rolników. ${ }^{15}$ Jednak w uzasadnionych sytuacjach możliwe jest odstępstwo od reguły przedsta-

13 Zob. postanowienie Sądu Najwyższego z 20 maja 1998 r., I CKN 668/97, LEX nr 749984: „Przepis art. 213 k.c. uzupełnia normę wyrażoną w art. 211 k.c. (oraz w art. 623 k.p.c.) w ten sposób, że kryterium podziału w naturze polegające na zgodności ze społeczno-gospodarczym przeznaczeniem rzeczy, zostało zastąpione pojęciem „zasad prawidłowej gospodarki rolnej”. Sprzeczność podziału gospodarstwa rolnego z tymi zasadami nakazuje wybór pretendenta do objęcia całości według kryteriów wymienionych w art. 213 k.c. i w art. 214 k.c."

14 Uchwała Sądu Najwyższego z dnia 4 grudnia 1970 r. III CZP 81/70, LEX nr 6835: „Kierowanie do dnia wejścia w życie k.c. gospodarstwem rolnym przez właściciela, który nie zamieszkiwał w tym gospodarstwie, czyni zadość przesłance prowadzenia gospodarstwa rolnego przewidzianej w art. 166 § 1 zd. 2 k.c. niezależnie od czasu trwania takiego stanu rzeczy." Zob. też dotyczący sformułowania prowadzenie gospodarstwa rolnego z ustawy o ubezpieczeniu społecznym rolników wyrok Naczelnego Sądu Administracyjnego (do 2003.12.31) we Wrocławiu z dnia 25 września 1981 r. SA/Wr 143/81, LEX nr 11251: „Pojęcie «prowadzenie gospodarstwa rolnego», zawarte w art. 2 ust. 2 ustawy z dnia 27 października 1977 r. o zaopatrzeniu emerytalnym oraz innych świadczeniach dla rolników i ich rodzin (Dz.U. Nr 32, poz. 140), należy rozumieć jako osobiste kierowanie i zarządzanie gospodarstwem, co do reguły wiąże się ze stałym osobistym wykonywaniem związanych z tym gospodarstwem prac i troską o jego należyte funkcjonowanie. Nie można zatem uznać, że warunek prowadzenia gospodarstwa rolnego spełniony jest zarówno wówczas, gdy rolnik użytkuje je osobiście, jak i wtedy, gdy oddał je w dzierżawę."

15 Zgodnie z art. 6 ustawy z dnia 20 grudnia 1990 r. o ubezpieczeniu społecznym rolników, tekst jednolity Dz.U. z 2013 r. Nr 1403 przez domownika rozumie się osobę bliską rolnikowi, która ukończyła 16 lat, pozostaje z rolnikiem we wspólnym gospodarstwie domowym lub zamieszkuje na terenie jego gospodarstwa rolnego albo w bliskim sąsiedztwie oraz stale pracuje w tym gospodarstwie rolnym i nie jest związana z rolnikiem stosunkiem pracy. 
wionej powyżej i przyznanie gospodarstwa rolnego nie osobie stale pracującej w gospodarstwie bądź je prowadzącej, ale innej osobie, jeżeli za jej wyborem przemawia interes społeczno-gospodarczy. Uznać należy, iż ustawodawca przyjął domniemanie, że przyznanie przedmiotu postępowania osobie stale pracującej w gospodarstwie rolnym bądź je prowadzącej jest zgodne z interesem społeczno-gospodarczym, chyba że w toku postępowania okaże się, że tak nie jest. Ustawodawca słusznie przyjął, iż zmiana podmiotu gospodarującego może ze swej natury negatywnie odbić się na produkcyjności gospodarstwa, ale jednocześnie pozbawić rolnika i ewentualnie jego rodzinę źródła utrzymania, często też miejsca zamieszkania. Za wyborem innej osoby winny przemawiać istotne argumenty zamknięte przez ustawodawcę w pojemnej formule.

Prawo słuszne i sprawiedliwe - to prawo uwzględniające interesy jednostki i interesy ogółu. Podstawowym celem zasady słuszności - objawiającej się przede wszystkim w szeregu klauzul generalnych - jest uelastycznienie prawa cywilnego poprzez uwzględnienie licznych wskazań aksjologicznych - moralnych, ale również społecznych, czy ekonomicznych. Tak właśnie jest w przypadku klauzuli interesu społeczno-gospodarczego, która została przez ustawodawcę wprowadzona w art. 214 jako dodatkowe kryterium, mogące w procesie ustalania osoby, której gospodarstwo rolne zostanie przyznane, przeważyć szalę na rzecz innego niż prowadzący gospodarstwo lub stale w nim pracujący współwłaściciel. Interes społeczno-gospodarczy występuje również w przepisach dotyczących znoszenia współwłasności zawartych w k.p.c. (art. 623 k.p.c.).

Zauważyć należy, iż w przypadku art. 214 k.c. mamy do czynienia z nałożeniem się interesu społecznego z interesem indywidualnym. Pojęcie interesu społeczno-gospodarczego jest przejawem z jednej strony ochrony produkcyjności gospodarstwa ze względu na jego istotną rolę dla gospodarki narodowej, z drugiej strony przejawem ochrony własności - takim jak art. 211 k.c. - nakierunkowanym na zapobieżenie utraty wartości określonego elementu majątku (gospodarstwa rolnego) na skutek nieracjonalnego podziału. Wprowadzanie reguł słuszności do prawa prywatnego odbywa się właśnie poprzez różnego rodzaju klauzule, ${ }^{16}$ tutaj reguła słuszności ma aspekt szerszy - uwzględniający interesy społeczeństwa, w tym interesy gospodarcze. Jest to reguła podobna jak przy ustalaniu barier prawa własności, którego granice stanowi właśnie społeczno-gospodarcze przeznaczenie prawa. ${ }^{17}$

Zob. M. Safjan, System..., op. cit., s. 356 na temat metod wprowadzania reguł słuszności do prawa prywatnego: „na pierwszy plan wysuwają się tu regulacje normatywne odwołujące się do zasad współżycia społecznego i dobrych obyczajów, zasad uczciwości obrotu, społeczno-gospodarczego przeznaczenia prawa".

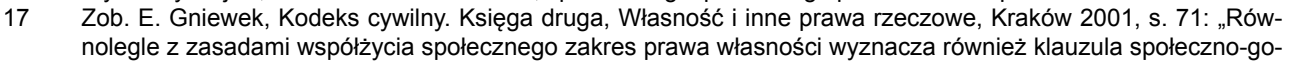
spodarczego przeznaczenia prawa. O ile jednak zasady współżycia społecznego wprowadzają do treści prawa własności czynnik moralny, o tyle klauzula społeczno-gospodarczego przeznaczenia prawa odwołuje się do funkcji ekonomicznej prawa. Należy bowiem zauważyć, że powołana klauzula hołduje funkcjonalnemu ujęciu praw majątkowych, przy równoczesnym zabezpieczeniu pierwszeństwa interesu społecznego przed indywidualnym." Zob. też Postanowienie Sądu Najwyższego z dnia 20 maja 1998 r. I CKN 673/97, LEX nr 1225369: „Pojęcie in- 
Tym samym w przypadku gospodarstw rolnych przy uwzględnieniu interesu ogólnego należy wziąć pod uwagę także interes jednostki. Interes społeczny - to nie tylko interes społeczeństwa jako całości, ale również, widziany przez pryzmat ogólniejszy, interes jednostki. Dlatego też sąd w szczególnych wypadkach powinien wziąć pod uwagę również interes osobisty, jednak uwzględniając ogólną regułę zasad współżycia społecznego. ${ }^{18}$ Podkreślić należy, iż chodzi tu nie tylko o względy produkcyjne, gospodarcze. Ustawodawca wyraźnie jako kryterium wymienia względy społeczne - a w tym pojęciu znajdzie się również ocena indywidualnej sytuacji danego współwłaściciela uwzględniająca szeroko rozumiany interes społeczny (więc również utrzymanie miejsc pracy, wielodzietna rodzina itd.) nie tylko czysto ekonomiczny. ${ }^{19}$

Warto podkreślić, że Kodeks cywilny posługuje się sformułowaniem „społeczno-gospodarczy" również w innych sytuacjach. W art. 5 k.c. występuje społeczno-gospodarcze przeznaczenie prawa. O społeczno-gospodarczym przeznaczeniu prawa jest mowa też art. 54 (regulacja dotycząca pożytków prawa). Również zgodnie z art. 140 k.c. - który określa uprawnienia właścicielskie i zakreśla granice prawa własności - właściciel może korzystać z rzeczy zgodnie ze społeczno-gospodarczym przeznaczeniem swego prawa. Art. 145 k.c., wskazuje, iż (§ 3) przeprowadzenie drogi koniecznej powinno uwzględniać interes społeczno-gospodarczy. ${ }^{20}$

Art. 5 k.c. wyraźnie odróżnia społeczno-gospodarcze przeznaczenie prawa od zasad współżycia społecznego. Interes społeczno-gospodarczy rozumieć więc należy przede wszystkim jako interes ogólny, nie indywidualny. Zasada słuszności w prawie cywilnym jest ukierunkowana, jak podkreśla M. Safjan, przede wszystkim na ochronę praw podmiotowych i indywidualnego interesu uczestników obrotu $\mathrm{w}$ przeciwieństwie do prawa publicznego, mającego za zadanie realizować

teresu społeczno-gospodarczego, które wymienia § 3 art. 145 k.c. nie zostało ustawowo zdefiniowane. Samo już określenie, iż chodzi o «interes społeczno-gospodarczy» wyznacza płaszczyznę jego oceny, przenosząc ją na grunt stosunków społecznych, w tym sąsiedzkich i rodzinnych i ekonomicznych czy gospodarczych uczestników postępowania. Dyrektywę uwzględnienia interesu społeczno-gospodarczego rozumieć należy w znaczeniu najogólniejszym, jako dążenie do tego, by ustalony szlak drożny odpowiadał potrzebom nieruchomości nie mającej dostępu do drogi publicznej i następował z najmniejszym obciążeniem gruntów, przez które ma przebiegać."

18 Zob. P. Księżak, Zniesienie współwłasności gospodarstwa rolnego (art. 213-217 kc.), „Monitor Prawniczy” 2013, nr 12, s. 624: „Interes społeczno-gospodarczy należy w tym kontekście odnieść do obiektywnych czynników warunkujących produktywność gospodarstwa rolnego. W zakresie interesu społeczno-gospodarczego nie mieści się natomiast interes ściśle osobisty jednego ze współwłaścicieli, ani tym bardziej interes majątkowy. Okoliczności osobiste czy majątkowe po stronie współłłaścicieli mogą przesądzić o odstąpieniu od kryterium z art. 214 § 1 k.c. jedynie wtedy, gdy mają taki charakter, że wpływają na racjonalność prowadzenia gospodarstwa (interes gospodarczy) lub stosunki społeczne (interes społeczny)."

19 Zob. postanowienie Sądu Najwyższego z dnia 26 lipca 2012 r. II CSK 738/11, LEX nr 1218159: „Problem wyboru pomiędzy współwłaścicielami, którzy prowadzą gospodarstwo rolne albo stale w nim pracują odpada, gdy jeden z nich nie chce prowadzić tego gospodarstwa. Ograniczenie wyboru sądu do wymienionych kategorii współwłaścicieli ustaje dopiero wtedy, gdy za przyznaniem gospodarstwa innemu współwłaścicielowi przemawia interes społeczno-gospodarczy. Innymi słowy, sądowi wolno przyznać gospodarstwo rolne współwłaścicielowi, który tego gospodarstwa nie prowadzi ani stale w nim nie pracuje wtedy, gdy interes społeczno-gospodarczy przemawia za wyborem innego współwłaściciela. Przy czym, interesu społeczno-gospodarczego nie należy rozumieć wąsko, wyłącznie w kategoriach ekonomicznych." 
interesy nie indywidualne, ale społeczeństwa ${ }^{21}$ Jednak w pełni należy zgodzić się ze zdaniem, iż „owa różnica perspektyw między prawem prywatnym a prawem publicznym nie oznacza, że w obszarze prawa prywatnego nie mogą się pojawiać rozwiązania i mechanizmy nawiązujące do wartości istotnych dla społeczeństwa jako całości. Jest wręcz przeciwnie. Prawo prywatne - jego mechanizmy i instytucje, są koniecznym warunkiem funkcjonowania społeczeństwa jako całości, a podejście ściśle indywidualistyczne jest uzupełniane przez elementy konstrukcyjne będące nośnikiem wartości ogólnych. Perspektywa indywidualistyczna nie przeczy więc temu, że w ramach sprawiedliwości wyrównawczej nie można sięgnąć do narzędzi korygujących ocenę określonych praw i interesów, wykraczającą poza czysto formalny aspekt wyrównawczy."22

Interes społeczno-gospodarczy nie może być więc rozumiany wprost jako podporządkowanie interesu indywidualnego - zbiorowemu. Jak wskazuje J. Nadler - odnosząc się do art. 140 k.c. „klauzula społeczno-gospodarczego przeznaczenia prawa wyraża nie tylko stosunek rolnika do społeczeństwa, ale i społeczeństwa do rolnika. Powinna ona wyrażać interes pożądany przez obie strony.”23

\section{Art. 214 § 2 k.c. najlepsza gwarancja należytego prowadze- nia gospodarstwa}

Przepis art. $214 \S 2$ k.c. odwołuje się do kolejnej klauzuli generalnej, jaką jest najlepsza gwarancja należytego prowadzenia gospodarstwa. Kryterium to jest decydujące przy wyznaczaniu osoby, której gospodarstwo rolne zostanie przyznane, w przypadku kumulatywnego spełnienia następujących warunków: braku zgody wszystkich współwłaścicieli oraz gdy kilku współwłaścicieli prowadzi gospodarstwo lub stale w nim pracuje, a interes społeczno-gospodarczy nie przemawia za wyborem innego współwłaściciela.

Przy ustalaniu, który ze współwłaścicieli daje najlepszą gwarancję należytego prowadzenia gospodarstwa rolnego pomocne mogą okazać się dyrektywy wypracowane w orzecznictwie na gruncie przepisów nieobowiązującej już ustawy z dnia 27 października 1977 r. o zaopatrzeniu emerytalnym oraz innych świadczeniach dla rolników i ich rodzin, ${ }^{24}$ gdzie wskazywano, że osoba, mająca zostać następcą rolnika, powinna obok kwalifikacji niezbędnych do przeniesienia własności nieruchomości rolnej, dawać faktyczną gwarancję należytego prowadzenia gospodarstwa rol-

21 Zob. M. Safjan, System..., op. cit., s. 355: „prawo cywilne kieruje się sprawiedliwością typu wyrównawczego (kumulatywną), nakierowane jest na ochronę praw podmiotowych i interesu prawnego uczestników obrotu, przywrócenie naruszonej równowagi w relacjach między podmiotami. W pewnym uproszczeniu mówiąc, realizuje koncepcję słuszności akcentującą równoważenie interesów w perspektywie relacji indywidualnych, a nie globalnych relacji społecznych, co jest domeną prawa publicznego." Ibidem, s. 355.

23 Tak J. Nadler, (w:) E. Gniewek (red.), Kodeks..., op. cit., s. 299.

24 Dz.U. Nr 32, poz. 140. 
nego. Jak bowiem argumentowano, ,taka wykładnia wydaje się odpowiadać intencji ustawy z dnia 27 października 1977 r., która zmierza do tego, aby gospodarstwo rolne było przekazane osobom dającym gwarancje podnoszenia produkcji rolnej i unowocześniania metod gospodarowania". ${ }^{25}$

Z powyższych względów, dokonując oceny, który ze współwłaścicieli daje najlepszą gwarancję należytego prowadzenia gospodarstwa rolnego sąd powinien wziąć pod uwagę całokształt okoliczności faktycznych, w tym zwłaszcza uwzględnić cechy osobiste oraz sytuację rodzinną i majątkową każdego ze współwłaścicieli. ${ }^{26} \mathrm{Jak}$ wskazuje P. Księżak, „chodzi (...) w pierwszym rzędzie o wybór współwłaściciela, który zna się na rolnictwie i zapewni prowadzenie w sposób efektywny gospodarstwa rolnego zgodnie z jego rolnym przeznaczeniem. Sąd rozstrzygający sprawę powinien wziąć pod uwagę konieczność zachowania odpowiedniej struktury agrarnej gospodarstwa rolnego, poprawę jego efektywności i wyników ekonomicznych, co pozostaje w ścisłym związku z potrzebą uwzględnienia interesów bytowych wszystkich współwłaścicieli gospodarstwa rolnego". ${ }^{27}$

Nie będzie więc miał przy wyborze znaczenia czynnik socjalny, a ocena utrzymania (zwiększenia) produkcyjności gospodarstwa rolnego jako jednostki gospodarczej. Prymat interesu ogólnego nad indywidualnym jest tu wyraźnie widoczny, istotne jest osiąganie przez rolnika odpowiedniego, społecznie pożądanego pułapu produkcji. Istotny jest więc los gospodarstwa rolnego, które powinno być prowadzone przez osobę z najlepszymi kwalifikacjami, posiadającą odpowiednie doświadczenie itd. ${ }^{28}$

W praktyce zdarzają się także sytuacje, w których współwłaściciel nie jest zainteresowany uzyskaniem gospodarstwa rolnego. Wówczas przyznanie mu gospodarstwa rolnego nie byłoby racjonalne. Dlatego też oczywiście w sytuacji, gdy współwłaściciel nie chce gospodarstwa objąć, traktuje się go tak, jakby warunku stałej pracy w gospodarstwie rolnym nie spełniał. ${ }^{29}$

25 Zob. uchwała Sądu Najwyższego z dnia 31 lipca 1979 r., III CZP 41/79, LEX nr 2397.

26 Zob. postanowienie Sądu Najwyższego z dnia 17 października 2000 r., I CKN 832/98, LEX nr 749993, w którym stwierdzono, że „ocena, który współwłaściciel daje najlepszą gwarancję należytego prowadzenia gospodarstwa rolnego, powinna być oparta na rozważeniu wyników postępowania dowodowego co do posiadanej przez współwłaścicieli wiedzy w zakresie rolnictwa, stosunków osobistych i rodzinnych współwłaścicieli, ich dotychczasowego źródła utrzymania oraz sytuacji życiowej i materialnej. Innymi słowy, zachodzi potrzeba uwzględnienia kwalifikacji podmiotowych, a nie odwoływania się jedynie do kwestii towarowości tworzonego gospodarstwa rolnego".

27 Zob. P. Księżak, Zniesienie współwłasności..., op. cit., s. 624-625.

28 Sąd Najwyższy w postanowieniu z 28 lipca 1999 r., II CKN 462/98 uznał, iż „ustalenie, że współwłaściciel żądający zniesienia współwłasności gospodarstwa rolnego przez jego podział nie prowadzi własnego gosodarstwa rolnego zgodnie z zasadami prawidłowej gospodarki rolnej, wyklucza możliwość przyjęcia spełnienia przez tego współwłaściciela gwarancji należytego prowadzenia gospodarstwa rolnego, o której mowa w art. 214 § 2 in fine" (niepublikowane, powołane za: S. Rudnicki, Komentarz do kodeksu cywilnego. Księga druga. Własność i inne prawa rzeczowe. Warszawa 2006, s. 316).

29 Zob. postanowienie Sądu Najwyższego z 11 listopada 1988 r., III CRN 356/88 LEX nr 8927: „Współwłaściciela gospodarstwa rolnego, spełniającego warunki nabycia nieruchomości rolnej (art. 214 § 1 k.c. w zW. z art. 160 § 1 k.c.), który nie chce prowadzić tego gospodarstwa, należy przy zniesieniu współwłasności traktować tak, jakby warunków tych nie spełniał." 
Klauzula najlepszej gwarancji należytego prowadzenia gospodarstwa ma w przeważającej części charakter ekonomiczny. Dobro gospodarstwa wysunięte jest na plan pierwszy, jednak nie można zapominać, iż ze względu na szczególną rolę gospodarstw rolnych w gospodarce narodowej, jako podstawowego producenta żywności oraz miejsca pracy dużej części społeczeństwa, klauzula ta ma również duże znaczenie społeczne. Jednak indywidualna sytuacja rolnika powinna być brana pod uwagę wyłącznie w przypadku oceny postępowania ze względu na zasady współżycia społecznego.

\section{Zasady przyznawania spłat - art. 216 k.c.}

Rola zasady słuszności widoczna jest również w przepisie art. $216 \S 2$ k.c., który $\mathrm{w}$ przypadku braku porozumienia $\mathrm{w}$ zakresie wysokości spłat przysługujących współwłaścicielom, nieotrzymującym gospodarstwa rolnego, umożliwia obniżenie spłat im należnych. Reguły określające stopień obniżenia spłat odwołują się do kryteriów słusznościowych. Obok bowiem kryterium typu, wielkości i stanu gospodarstwa rolnego, będącego przedmiotem zniesienia współwłasności pojawia się kryterium sytuacji osobistej i majątkowej współwłaściciela zobowiązanego do spłat i współwłaściciela uprawnionego do ich otrzymania.

Za podstawową przesłankę dotyczącą stosowania art. $216 \S 2$ k.c. należy uznać dobro ekonomiczne gospodarstwa jako jednostki produkcyjnej kierując się konstytucyjną zasadą ochrony gospodarstwa rodzinnego. Przy stosowaniu omawianej regulacji należy przede wszystkim kierować się analizą ekonomiczną, względy społeczne mają znaczenie ewentualnie przy ocenie zdolności rolnika do prowadzenia gospodarstwa rolnego i jego zdolności finansowych dotyczących majątku poza gospodarstwem rolnym. ${ }^{30}$

\section{Wnioski}

Regulacja dotycząca zniesienia współwłasności gospodarstwa rolnego jest przejawem tendencji do uelastycznienia regulacji prawnych, która realizowana jest poprzez odwołanie się do klauzul generalnych. Jest to regulacja o tyle istotna, że wszelka ingerencja za pomocą klauzul ogólnych w prawo własności może rodzić i rodzi spory. $Z$ drugiej jednak strony, posłużenie się przez ustawodawcę pojęciami niedookreślonymi daje sądowi rozstrzygającemu sprawę pewien luz decyzyjny,

Szerzej J. Bieluk, Zasada słuszności a art. 216 § 2 k.c., „Białostockie Studia Prawnicze” 2008, nr 3. Zob też Trybunał Konstytucyjny w postanowieniu z dnia 20 marca 2013 r. P 35/2011, (z uzasadnienia): „Wobec specyfiki przedmiotu współwłasności, jakim jest gospodarstwo rolne - jednostka gospodarcza o wysokim wskaźniku wymaganego nakładu pracy i kapitału oraz stosunkowo niskiej dochodowości - idzie o to, aby zapewnić egzystencję i zdolność gospodarczą rolnika zobowiązanego do zapłaty, a równocześnie zagwarantować pozostałym współwłaścicielom stosowny ekwiwalent." 
umożliwiając skorygowanie zasad znoszenia współwłasności wynikających z przepisów prawa. Niewątpliwie ogólne formuły interesu społeczno-gospodarczego oraz należytej gwarancji właściwego prowadzenia gospodarstwa rolnego ingerują bezpośrednio w prawo własności i przez to sprawiają, iż najszersze prawo podmiotowe ulega relatywizacji. Nie jest to jednak relatywizacja bezzasadna. ${ }^{31}$ Jest to oparcie się na innych, równie istotnych wartościach, takich jak konstytucyjna ochrona gospodarstwa rodzinnego oraz społeczna i gospodarcza rola rolnictwa jako dostarczyciela żywności.

Ograniczenie prawa podmiotowego zawarte w art. 213 i 214 k.c. (również w art. 216 k.c.) ma swoje uzasadnienie. Przejaw zasady słuszności ma zabarwienie ekonomiczne, jednak nie można tracić z oczu uzasadnienia szerszego. W pełni należy zgodzić się z Sądem Najwyższym, iż ,interesu społeczno-gospodarczego nie należy rozumieć wąsko, w kategoriach wyłącznie ekonomicznych, nie jest to bowiem interes tylko gospodarczy. Szczególnie przy stosowaniu art. 214 § 1 k.c. do działu spadku (w związku z art. 1070 k.c.), zachodzi potrzeba rozważania interesu społeczno-gospodarczego w aspekcie sytuacji osobistej i rodzinnej spadkobierców". ${ }^{32}$

Zauważyć należy, iż ustawodawca wyraźnie daje priorytet zasadzie ochrony gospodarstwa rolnego jako jednostki produkcyjnej. Regulacja kodeksowa dotycząca zniesienia współwłasności gospodarstwa rolnego zawiera szereg sformułowań niedookreślonych, które mają za zadanie z jednej strony zapobiec gospodarczo i społecznie nieuzasadnionym podziałom gospodarstw rolnych, z drugiej - uelastycznić kryteria przyznawania gospodarstwa rolnego (wyboru między współwłaścicieli).

Wprowadzone rozwiązanie pozwala na stosowanie szerokich kryteriów. Z pewnością jednym z nich powinna być zasada słuszności, której elementy możemy dostrzec przede wszystkim w klauzuli interesu społeczno-gospodarczego, dającego możliwość zmiany osoby prowadzącej gospodarstwo rolne. Klauzulę powyższą rozumieć należy zarówno w kontekście gospodarczym - ochrona produkcyjności gospodarstwa, jak i społecznym - w tym również analiza sytuacji majątkowej oraz osobistej.

Zestawiając przepisy regulujące zasady znoszenia współwłasności gospodarstw rolnych z przepisem art. 5 k.c. należy zauważyć, że art. 5 k.c. jest jedynie mechanizmem obronnym. Natomiast klauzule generalne zawarte bezpośrednio w art. 213 i 214 k.c. kształtują aktywnie rzeczywistość i wpływają na prawa podmiotowe, da-

31 Zob. M. Safjan, System..., op. cit., s. 356-357.

32 Postanowienie Sądu Najwyższego z dnia 6 maja 1999 r. II CKN 313/98, LEX nr 523660: „Innym zagadnieniem jest kwestia zgodności zaskarżonego orzeczenia z art. $214 \S 1$ k.c. Jest to przepis dotyczący zniesienia współwłasności gospodarstwa rolnego, szczególny w stosunku do art. 211 k.c. o tyle, że daje pierwszeństwo w otrzymaniu gospodarstwa w naturze, temu ze współwłaścicieli, który je prowadzi lub stale w nim pracuje. Pierwszeństwo to nie ma charakteru bezwzględnego. Z uwagi na interes społeczno-gospodarczy Sąd może wybrać innego współwłaściciela. Trafny jest pogląd Sądu Wojewódzkiego, że interesu społeczno-gospodarczego nie należy rozumieć wąsko, w kategoriach wyłącznie ekonomicznych, nie jest to bowiem interes tylko gospodarczy. Szczególnie przy stosowaniu art. 214 § 1 k.c. do działu spadku (w związku z art. 1070 k.c.), zachodzi potrzeba rozważania interesu społeczno-gospodarczego w aspekcie sytuacji osobistej i rodzinnej spadkobierców." 
jąc sądowi większą swobodę w decydowaniu o losach gospodarstwa rolnego. Należy w pełni zgodzić się ze stanowiskiem Trybunału Konstytucyjnego, że „wbrew obiegowo przyjmowanej opinii, rozwiązanie zawarte w art. 213 i $214 \mathrm{kc}$ nie stanowi jedynie swoistego reliktu okresu PRL; nie ma też charakteru wyjątkowego w skali europejskiej". ${ }^{33}$ Jest to przejaw dążenia do uelastycznienia prawa, zbliżenia sztywnych rozwiązań ustawowych do rzeczywistości, odwołania do norm pozaustawowych. 


\section{ABOLITION OF A FARM CO-OWNERSHIP IN THE CONTEXT OF THE PRINCIPLE OF EQUITY}

Regulations concerning the dissolution of ownership described by the Civil Code Articles 213-218, contain a series of general concepts. Among them are the clause of socioeconomic interest and of providing due guarantee of proper running of the farm. The article discusses relations between the above mentioned clauses and the clause of the principle of equity. In the regulation pertaining to the dissolution of a farm economic criteria visibly prevail. Still, one may notice that, particularly in the notion of socioeconomic interest, there are elements referring to the principle of equity.

Keywords: farm, farm co-ownership, clause of socioeconomics interest, guarantee of proper running of the farm 